\title{
Modelling anthropological profile by communication
}

\author{
Bianca Teodorescu \\ University of Craiova, 13 A. I. Cuza Street, Craiova, 200585, Romania \\ E-mail address: valentino_busu@yahoo.com
}

\begin{abstract}
The role of the communication is to form and organize all the activities in a society. The communication intervene in antropological profile of human beings. The communicator consumes the information in a proper way to be understood by the collective in which he lives. In the process of communication, the informational contact between the people is generating by needs, aspiration, interest, ideas and attitudes. Any type of human organization is producing contacts and communication and has the role to imply it the effects on the society. Based on the importance of the information that is received, people evaluate the trends and knowledge on decision that are taken. In a global setting, the information, ideas and subject are all common, but they also can be diversified and adapted in function with the reality.
\end{abstract}

Keywords: antropological profile; communication; information; society

\section{INTRODUCTION}

We are communicating with the people around us through different channels and we give and receive the necessary and correct information.

A human contact with the others has the role of modelling his perceptions and beliefs about the world and to change his attitudes and behaviour. All the actions are taking place to different levels of social structure with various role.

Any cognitive activity is an anticipation that substantiates strategy of feedforward. The systematic strategy consists of adapting to the purpose that can lead to a better conversion in the communicative act.

Communication represents the most important elements for a human collectivity to functionally proper. The change of messages can generate some points of view and actions through harmonization of knowledge on purposes, paths and means for their can they be achieved. If we want to understand the received messages on different channels of communication to different interlocutors, we must know that the notion of communication means also the community with all the existence of the groups and social systems. Thus, the communication implements the idea of participation to the group's mental level.

\section{ACTIONS, TOOLS AND PRICIPLES}

In the theory of communication exists two forms of actions: feedforward and feedback. Feedforward has the role to anticipate and control the future, but his function is correlated to 
the feedback (Vlăduțescu, 2013; Vlăduțescu, 2014). Through this mechanism the information is produced and sent to prepare the control part of the system for a future action.

The feedforward is presented as a tool for comparing current operation with the anticipated and controlled operation The moment of state is reported to an accurate state and is not a simple and innocent essence, but a force of domination in evolution with the tendency to a direction. The present is a structure based on human systems, organizations, institutions and self monitoring systems. The future has a past and the past is a product of the future. If the past is represented by a project and the future is composed by a projection of the past, it means that the present is the place where the direction is constituted.

Feed forward assumes four operations. The first is about a system analyst and consist in collecting the information with all the functions, projects and projections relying on planning the system objectives and strategies. It is analysed by structure system, functioning system and production system.

The second operation represents an analysis of environment system for recording the impact of external evaluation on the good function of the system. The third operation consists in analysing the comparative possibility in intern parameters of the system and in report with the environment; the system follows to achieve its objectives. On another hand, this operation consists in taking the decision regarding optimizing the parameters of the system and reforms and restructures the system. This operation follows to create an alternative future in taking the right decisions.

The fourth operation implements the decision in the manner the objectives to be achieved.

As an adaptation to a behavior through the advancement of measure in which they have to allow a good conversion in the action, the feed forward consists in prevision and anticipation of system evolution in persuading the purpose. In feedback, the decision must be taken in the report with a fast image, instead in the feed forward, the decision place an anticipated image of the future state of the system. Both are strategies in which the system proceeds at the present moment in adaptation to the intern and external problems. The first strategy compares the response between past and present and the second validities the past through the present. The energy and the information are a part of the objectives: a well adapted in the present to an onus from the past or a good adaptation in the future to a task of the present that can have or not a past. Feedback is a part of the control system. Acting in persuading its purposes, the execution is compared to an initial state. The feedback has important parameters: variable object (informational and actionable), finalization (positive and negative), time (the interval in deviation in which the phenomenon can be controlled as a system's element-factor without a radical transformation to another system), amplitude (modification produces through feedback), levels and gaps (the report between variation and interventions). The system's state is defined by the constant factors and variable (reliable factors).

The reverse connection provides the information on execution, finalization and achievement of its purpose. If the execution can't correspond as an efficiency with the objectives, it has to create a correction of the programs to sampling the information to change the decisions and adopt other measures for a cognitive behaviour. It is important to know about the feedback that the information has to allow the system to continuous surveillance the activity.

An inappropriate feedback can bring major bad decisions: a wrong decodification of the message may result in a non-communication action of a two person or a group. 
For a man, the concept of the information creates the power of knowledge and can exploit his informational environment (other natural phenomena, discussions, books, movie, situation).

Our society consists in principles (propositions-protocol-based statements) or golden rules; we cannot think if we don't have principles (without identity). A disorder organization can destroy the society. Without principles, the information cannot have efficiency. The formulation of its principles makes the information easily accessible and bring safety to our life in the information era and informational society. Our contribution is not based on the instruments and highlight. They had been outlined in fundamental previous studies, but the principles can be uncertain and imprecise in the science of the information.

The first principles of information are the impossibility to inform. It represents an extension of the first communication axiom "It is impossible to not communicate". Any communication implies an information, but it's base it not necessary the information, it can be collateral. Through its implication, this principle can bring qualification in the action of the two communication axioms. It appears that the communication aspects (content and relation) provide the information and the reports in the communication exchanges. The second principles it is about the ontological part, the signification represents the material from whom the information is presented. To create the informational structure, we must have all the available signification for an organization with the help of the instruments, after a conceptual structure.

The third principle is about ranking the information and represents the elements that compose an information and how the complex networks can formes an image. Signification are perceive and are structured as an integer. The information is meaning signification. In every information we find at least two information formed by subject and predicate. Information is organized hierarchically and its orientation is the most significant. C.J. Filmore presents an example: "Close the door!". This sentence has five information:

- between the broadcaster and the receiver is a special relation where the first is in a position to ask anything

- the receiver is capable and has possibility to close the door

- the broadcaster is visioning some door and has reason to believe that the receiver knows about what he is talking

- the broadcaster wants the door to be closed so he says: "Close the door!"

The principle of informational selectivity is the fourth principle that is represented by the cognitive subject in manner to be active in the report with it knowledge. Selectivity can be the order of necessity: the limits of processing capacity or the order of efficiency: it's easier to process. Any selection targets the informational object. The cognitive subject has a plenty of significations and it can't structure all the information; human subject is orientated on a specific aspect and it is selected as an object of knowledge, of information. All these significations are eliminated.

The fifth principle is about loss of information. Decreasing the information in processing and transmission is determined by the number of the novelty in which it becomes knowledge. Thus, the number of the novelty will increase the information.

The word information can be misleading. The concept of information has presented a confusing character with a significant value and it represents the essential activity of people in a society.

For many organizations, the information is one of the most valuable and important sources of it. Information is a collection of facts represented by some essential question: 
Why? Where? When? Who? - are organized as their value to be superior of facts' amount. This concept is not the same with dates and knowledge, so the information can be defined representing organized dates, and knowledge as understood information.

There are ten significations of informational concept:

- something unknown

- solution of unwanted situation

- modality of dates' interpretation

- something useful in the process of decisions

- something useful to a person

- something that has influence on known of things

- the sense of words in a phrase

- something that reduces uncertainty

- something that is a result of the words

- something that has effect about the believe of a person

Processing the information decrease the novelty of it. The information is like an impact and an informational shock pass through processing. To create new ways to multiple processes make the information to be a lost. If information is heard two times, it means that it is not information. In a primary mode we heard the information and the second we heard something known. Through processing, the difference between the novelty and the known is resulting from decreasing.

Benefit in accordance is the last principle of information, principles that make available a producer and consumer constant. It has the role of action through informational selection and scales of values and it is representing an attention about the possible inertial effects. The information following the plan (composed by waiting system) has an attention priority which is relevant and valuable.

Production and consumer of information can confirm fears, hopes, prejudices, knowledge and anticipation about informational producer. Any information is based on expectations and anticipation. In all this process, a risk in information is representing the prejudices, fears, hopes or our anticipation. The information does not exist, it depends on broadcaster and it suggests that a consumer covers the involuntary errors of the producer.

\section{CONCLUSION}

Communication is more stable as it is isolated from the information. Communication forms a system with a dynamic stability and it can be changed by a transformation consisting in perfecting the process. A good communication structure is defined and properly modeled for a powerful organization with the purpose to increase due possibly to adapt to the system. It is not just a thought or a feeling. To communicate implies to inform, to listen. The first information that we receive in the process are coming from the evolution of communication and it can be confirmed or infirmed. 


\section{References}

[1] A. Duranti (Ed.). (2009). Linguistic anthropology: a reader (Vol. 1). John Wiley \& Sons.

[2] Nicolae Panea (2013). Orașul subtil. București: Editura Etnologică.

[3] Andrzej Borowski, International Letters of Social and Humanistic Sciences 14 (2014) 7-17.

[4] C. Geertz (1983). Local knowledge: Further essays in interpretive anthropology (Vol. 5110). Basic books.

[5] C. Lévi-Strauss (2008). Structural anthropology. Basic Books.

[6] Aurelia Traistaru (2013). Consolidation of the green marketing profile in current austerity period. Jokull.

[7] Mihai Coman, Media anthropology (2005) 46-55.

[8] Ştefan Vlăduţescu, European Scientific Journal 9(32) (2013).

[8] Mihai Coman (1999). Introducere în sistemul mass-media. Polirom.

[9] Andrzej Borowski, International Letters of Social and Humanistic Sciences 4 (2013) 70-74.

[10] Bartłomiej Okwiet, Alina Țenescu, Adrian Nicolescu (2014). Social, communicational and law responsibility in multinational companies. Topical Communication Uncertainties, 149.

[11] J. Fabian (2014). Time and the other: How anthropology makes its object. Columbia University Press.

[12] H. R. Bernard (2011). Research methods in anthropology. Rowman Altamira.

[13] M. H. Fried (1967). The evolution of political society: An essay in political anthropology (Vol. 7). New York: Random House.

[14] R. G. d'Andrade (1995). The development of cognitive anthropology. Cambridge University Press.

[15] M. Douglas (1999). Implicit meanings: Selected essays in anthropology. Psychology Press.

[16] A. Sandu (2009). Tehnici afirmativ-apreciative. O sociopedagogie a succesului. Lumen.

[17] Nicolae Panea (2001). Zeii de asfalt, antropologie a urbanului. București: Cartea Românească.

[18] Andrzej Borowski, International Letters of Social and Humanistic Sciences 14 (2014) $33-41$.

[19] Ștefan Vlăduțescu, International Letters of Social and Humanistic Sciences 10 (2014) $100-106$.

[20] Andrzej Borowski, International Letters of Social and Humanistic Sciences 6 (2013) 86-90. 
[21] Janusz Grabara, Michal Kolcun, Sebastian Kot, International Journal of Education and Research 2(2) (2014).

[22] Nicolae Panea (2012). Antropologie Culturală Americană. Craiova: Editura Universitaria.

[23] Sebastian Kot, Beata Ślusarczyk (2014). IT Role in Supply Chain Collaboration. Current Communication Difficulties, 165.

[24] Mihai Coman (1999). Introducere în sistemul mass-media. Polirom.

[35] Florentin Smarandache, Stefan Vladutescu, Revista de Cercetare şi Intervenţie Socială, 46 (2014) 243-254.

[26] A. Caras, A. Sandu, Procedia-Social and Behavioral Sciences 149 (2014) 142-151.

[27] A. Sandu, Postmodern Openings 3 (2014) 49-66.

[28] Paula Bajdor, Iwona Grabara, Journal of Studies in Social Sciences 7(2) (2014).

[29] J. H. Gasderell, International Letters of Social and Humanistic Science 22 (2014) 85-91.

[30] Ștefan Vlăduțescu, Florentin Smarandache, Daniela Gîfu, Alina Țenescu (2014). Topical Communication Uncertainties. Craiova/Columbus: Sitech/Zip Publishing.

[31] Mihai Coman (2003). Mass-media, mit și ritual. Iași: Editura Polirom.

[32] Ştefan Vlăduţescu, American International Journal of Contemporary Research 3(10) (2013).

[33] G. Rajović, J. Bulatović, International Letters of Social and Humanistic Sciences 6 (2013) 24-35.

[34] Antonio Sandu, Elena Unguru (2014). Acțiune comunicativă, justiție deliberativă și restaurativă. București: Editura Tritonic.

[35] Ștefan Cojocaru (2005). Metode apreciative în asistența socială: ancheta, supervizarea, studiul de caz. Polirom.

[36] Florentin Smarandache, Ștefan Vlăduțescu, Alina Țenescu (2014). Current Communication Difficulties. Craiova/Columbus: Sitech/Zip Publishing.

[37] D. Cojocaru, A. Sandu, S. Cojocaru, Journal for the Study of Religions and Ideologies 28 (2011) 65-83.

[38] A. C. Strunga, C. M. Bunaiasu, Revista de cercetare şi intervenţie socială 40 (2013) 61-77.

[39] O. M. Cuichi, C. Bragaru, S. Cojocaru, Revista de Cercetare şi Intervenţie Socială 36 (2012) 31-43.

[40] Xenia Negrea, Revista de Stiinte Politice 24 (2009).

[41] Andrzej Borowski, International Letters of Social and Humanistic Sciences 14 (2014) 7-17.

[42] Max G. Craig, Journal of Studies in Social Sciences 8(1) (2014).

[43] Jason L. Powell, International Letters of Social and Humanistic Sciences 17(1) (2014) $1-60$. 
[44] Savo Karam, International Letters of Social and Humanistic Sciences 28 (2014) 77-84.

[45] Roland Lami, International Letters of Social and Humanistic Sciences 29 (2014) 78-81.

[46] Wessam Al Chibani, International Letters of Social and Humanistic Sciences 30(2) (2014) 192-197. 